\title{
Kirjoituskutsu Avaimen numeroihin 1 ja 3/2021
}

Kutsumme kirjoittajia Avaimen vuoden 2021 ensimmäiseen ja kolmanteen numeroon. Toivomme mukaan kirjallisuudentutkimukseen liittyviä tieteellisiä artikkeleita sekä muita kirjallisuutta ja kirjallista elämää käsitteleviä esseitä, katsauksia, puheenvuoroja, haastatteluja ja kirja-arvosteluja. Arvosteluja toivomme niin kotimaisesta kuin ulkomaisesta tutkimuskirjallisuudesta sekä muista kirjallisuustieteellisistä julkaisuista.

Refereeartikkelin pituus tulee olla 20 000-40 000 merkkiä välilyönteineen. Kirja-arvostelujen ohjepituus on 5000-7000 merkkiä välilyönteineen. Muita kirjoituksia varten on kaksi kategoriaa, joista pidempi voi olla $15000-30000$ ja lyhyempi 10 000-20 000 merkkiä välilyönteineen. Pidemmän kirjoituksen aiheeksi sopii kirjoitus, jossa aineiston kuvauksen ja analyysin sijasta keskitytään (kirjallisuuden)tutkimukselliseen teemaan, teoreettiseen keskusteluun tai metodologiaan. Lyhyemmiksi jutuiksi kutsumme yleistajuisia ja laajalle yleisölle sopivia tekstejä kirjallisuuteen, kirjallisuusinstituutioon tai sen tutkimukseen liittyvistä ajankohtaisista ilmiöistä. Tyyliltään ja muodoltaan vapaamuotoisempia lyhyempiä kirjoituksia jaetaan linkkien välityksellä kirjallisuudesta kiinnostuneelle yleisölle sosiaalisessa mediassa ja kirjallisuuteen keskittyvillä sivustoilla.

Ehdotukset refereeartikkeleiksi lähetetään valmiina käsikirjoituksina. Esseiden, katsausten, arvostelujen ja haastattelujen aiheet voivat olla vapaamuotoisempia.

Numeron 1/2021 artikkelimuotoisten ehdotusten deadline on 30.11.2020. Muiden kirjoitusten toimitusaikataulusta sovitaan erikseen päätoimittajien kanssa, mutta niiden deadline on 7.1.2021.

Numeron 3/2021 artikkelimuotoisten ehdotusten deadline on 12.4.2021. Muiden kirjoitusten toimitusaikataulusta sovitaan erikseen päätoimittajien kanssa, mutta niiden deadline on 19.5.2021.

Otamme jatkuvasti vastaan artikkeleihin, arvosteluihin ja muihin teksteihin liittyviä julkaisuehdotuksia seuraavia numeroita ennakoivasti.

Kirjallisuudentutkimuksen aikakauslehti Avain käyttää digitaalista OJS-julkaisujärjestelmää journal.fi. Järjestelmää käytetään myös lehden toimitustyössä. Kirjoittajien tulee kirjautua järjestelmään journal.fi-sivuston kautta ja tarjota artikkeleita ja muita kirjoituksia sen kautta. Mikäli kirjautumisessa on ongelmia, pyydämme ottamaan yhteyttä toimitussihteeriin (jari.kakela_at_gmail.com).

Kirjoituksia koskevissa muissa kysymyksissä ottakaa yhteyttä päätoimittajiin: Lotta Kähkönen (lotta.kahkonen_at_utu.fi) ja Riitta Jytilä (riijyt_at_utu.fi).

Avaimen ohjeet kirjoittajille löytyvät lehden journal.fi-sivuilta: https://journal.fi/avain/about/submissions. 


\section{Abstracts}

Jyrki Korpua

\section{From the Wuhan-400 to the Blue Project and the Georgian-Viruses as Elements of Horror in Dystopian Fiction}

This article is concerned with viruses as elements of horror in Stephen King's The Stand (1978), The Eyes of Darkness (1981, edit. in 1989) by Dean R. Koontz, and Emily St. John Mandel's Station Eleven (2014). It suggests that viruses are crucial devices in these dystopic novels. The article examines the origin of the viruses, transmission of the viruses, and how characters react to the viruses in the novels. A specific point of interest of the article is on the genre logics of the novels. The article partakes in the topical discussion of viruses in fiction that has become abundant since the outbreak of global COVID-19 pandemic.

Keywords: The Eyes of Darkness, horror fiction, pandemic, The Stand, Station Eleven, virus

\section{Annukka Immonen}

\section{Metonymicity of Affective Experiences in Sirkka Turkka's Poem "Deep in the Forest a Big Moose Is Sleeping"}

This article examines how being in the world and modes of experience of the lyric I are represented and conveyed in Sirkka Turkka's poem "Deep in the Forest a Big Moose Is Sleeping". The article is drawing on enactive and phenomenological views of feelings combining them with studies of metonymy in order to demonstrate how the poem disentangles Cartesian distinctions between mind and body, reason and feelings, culture and nature, and human and animal, which have been constructed in Western thought. The analysis points out how the lyric I is through her embodied mind, affective states, and sense-making metonymically part of her environment and attuned to the world. In spite of her culturally and anthropomorphically coloured perspective the lyric I is located on the same metonymic continuum of living organisms as the representatives of nature in the poem. The article shows how the lyric I, through metonymicity and other figurative devices, projects, confronts and processes difficult existential 
feelings and emotions that intertwine with them. Speechlikeness of the poem gives an impression of authenticity and intimacy of the experiences depicted. However, there are rhetorical tools that create the overall aesthetic atmosphere of the poem. Along with metonymicity, especially phonetic repetition and typographical choices evoke affectivity, dynamicity, and the sense of agency. Finally, the atmosphere of the poem appears to be an interaffective construction in which the reader is metonymically embedded.

Keywords: affectivity, enactivism, existential feelings, metonymicity, phenomenology, Sirkka Turkka

\section{Päivikki Romppainen}

\section{The Apostrophe in Paavo Rintala's Novel Sarmatian Orfeus}

In this article, I discuss the use of apostrophe in Paavo Rintala's novel Sarmatian Orfeus (1991). Rintala's novel is constructed around the long textual dialogue between the narrator and the absence of his late poet friend Johannes Bobrowski. I argue that despite this intense dialogism, the apostrophe functions as a metatextual tool that intensifies the absence of the addressed rather than creating an illusion of a presence. This becomes even more evident when the apostrophe is used in the context of addressing persons and entities that are either dead, inanimate, or abstract ones, like the month of April. Apostrophe is also used at several textual levels. The first is the level of Johannes Bobrowski's poems, three of which Rintala has translated in their entirety. The second level is the narrator addressing Bobrowski and other historical personages like Henri Beyle/ Stendhal, or addressing abstract entities. The third level is the cover of the book, illustrating Bobrowski's letter and thus addressing the reader. I claim that while the text creates an intense tension between dialogism and absence, the reader is simultaneously enticed into feeling empathy towards others' stories but still maintaining the critical distancing needed for genuine ethical reflection. The others' stories and otherness maintain their independence, but in doing so they offer the reader increased possibilities for ethical reflection beyond one's own historically limited horizons.

Keywords: apostrophe, ethics of reading, Johannes Bobrowski, Paavo Rintala 


\section{Kaisa Kortekallio \&Anna Ovaska}

\section{Close Reading Then and Now: \\ Embodied, Environmental and Political Perspectives}

In this article, we explore the embodied, environmental and political dimensions of close reading as well as its applications in and outside of literary studies. First, we discuss some historically important, yet underappreciated notions of close reading. In our view, the widely accepted New Critical conception of close reading, which emphasizes objective and critical reading methods and strict focus on the text, can be challenged by considering the work of thinkers who understood close reading as a cultivation of reflective transaction between the reader and the text. Such thinkers paid special attention to the fact that readers are embodied beings who read texts in specific material environments and socio-cultural and political situations. In our interpretation, this "alternative" history of close reading begins with I. A. Richards, Virginia Woolf and Louise Rosenblatt, and extends through feminist narrative studies to new formalism and current enactivist theories. In the second part of the article, we discuss recent applications of close reading which also draw from the embodied, environmental and political notions of reading. We examine how close reading has been employed as a method in medical humanities and environmental humanities, more specifically in narrative medicine and posthumanist/ecocritical research. We also elaborate on the value of close reading in the digital age and discuss its possible social and political implications.

Keywords: close reading, enactivism, feminist literary studies, narrative medicine, new formalism, posthumanism 


\section{Tule jäseneksi Kirjallisuudentutkijain Seuraan!}

Jäsenenä saat seuran julkaiseman Avain-lehden neljästi vuodessa sekä oikeuden osallistua seuran järjestämiin seminaareihin ja muihin tilaisuuksiin.

\section{Kirjallisuudentutkimuksen aikakauslehti Avain}

Kirjallisuudentutkimuksen aikakauslehti Avain on tapa päästä sisään kirjallisuudentutkimuksen maailmaan. Se tarjoaa tieteellisten artikkelien, tutkimus- ja kirja-arviointien lisäksi erilaisia puheenvuoroja kotimaisesta ja ulkomaisesta kirjallisuudesta ja sen tutkimuksesta. Lisäksi se pyrkii herättämään keskustelua kirjallisuudentutkimukseen liittyvistä ajankohtaisista aiheista.

Avain jatkaa kirjallisuudentutkimuksen äänitorvena seuransa 90 vuoden kokemuksella.

Neljästi vuodessa ilmestyvä Avain on Kirjallisuudentutkijain Seuran lehti, jonka saa seuran jäsenetuna maksamalla jäsenmaksun 48 euroa (perustutkinto-opiskelijat, apurahatutkijat, työttömät ja eläkeläiset 27 euroa) Seuran tilille FI90 800012014734 45. Viestikenttään merkitään jäsenen nimi ja osoite lehden postitusta varten.

Ilmoittamalla sähköpostiosoitteesi seuran sihteerille Marianna Koljoselle (sihteeri.kts@gmail.com) pääset mukaan myös seuran postilistalle kts@uta.fi, jolla tiedotetaan alaan liittyvistä tapahtumista. Listaa käytetään myös tiedonhankintaan, sekä keskusteluun kirjallisuutta ja kirjallisuudentutkimusta koskevista ajankohtaisista aiheista.

Lisätietoja seurasta: http://pro.tsv.fi/skts/ 
Sananjalka on vuodesta 1959 lähtien ilmestynyt laadukasta humanistista tutkimusta julkaiseva tieteellinen vuosikirja.

Sananjalassa julkaistaan vuosittain noin kaksitoista vertaisarvioitua artikkelia suomen ja sen sukukielten, kotimaisen kirjallisuuden, folkloristiikan, kansatieteen, uskontotieteen ja arkeologian alalta. Lisäksi vuosikirja tarjoaa luettavaksi kiinnostavia katsausartikkeleita ja arvosteluja tuoreista humanistista alaa koskettavista kirjoista.

Sananjalkaa julkaisee vuonna 1929 perustettu Suomen Kielen Seura.

\section{Sananjalka}

Numerossa 62 muun muassa :

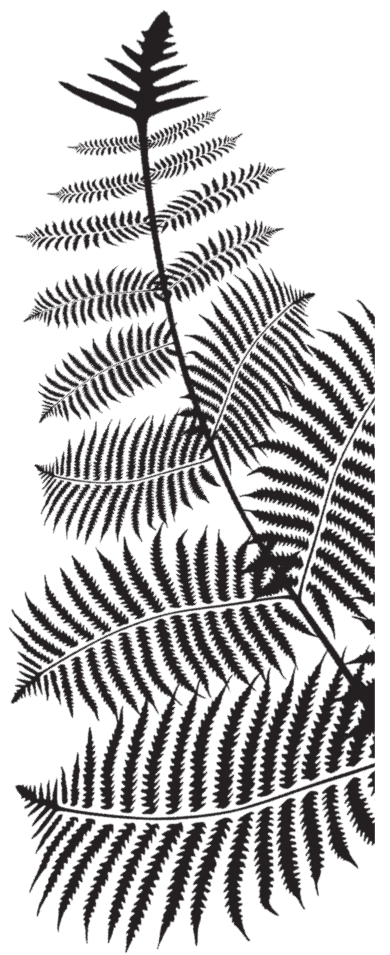

Hannele Forsberg ja Milla Uusitupa: Yksikön 2. persoonan avoimen käytön levikki ja yleisyys suomen murteissa

KARITA SUOMALAINEN: Tiedätkö - kysymyksestä kiteymäksi.

JusSI YLIKOSKI: Eesti maakonniti ja Suomen maakunnittain: viron ja suomen kääpiösijat rinnakkain.

JaAna VAaHTERA ja Minna SePPÄnEn: Varhaisimmat suomenkieliset kreikan ja latinan kieliopit suomalaisen sivistyksen asialla

ELLI LEHIKOINEN: Luonnon, uskon ja eron voima: Lisääntymisen luvat Pauliina Rauhalan Taivaslaulussa.

Lisäksi uusimmassakin numerossa on runsaasti muita artikkeleita, katsauksia ja kirja-arvosteluja.

Tilaukset: $\quad$ Tiina Parjanen, sananjalka@utu.fi Päätoimittaja: Paula Sjöblom, sananjalka@utu.fi Toimitussihteeri: Minerva Piha, sananjalka@utu.fi 